Al-Manhaj: Journal of Indonesian Islamic Family Law, 1 (2), 2019: 141-160

ISSN: 2715-003; E-ISSN 2714-5514

DOI: http://dx.doi.org/10.19105/al-manhaj.v1i2.3129

\title{
Efektivitas Pencegahan Pernikahan Dini \\ Pada Kantor Urusan Agama Kecamatan Gondomanan Yogyakarta Tahun 2014-2015
}

\author{
Theadora Rahmawati, Qorry 'Aina \\ (Fakultas Syari' ah dan Hukum UIN Sunan Kalijaga Yogyakarta, Jl. Laksda \\ Adisucipto, Papringan, Caturtunggal, Kec. Depok, Kabupaten Sleman, \\ Daerah Istimewa Yogyakarta 55281)
}

\begin{abstract}
Abstrak
KUA Gondomanan merupakan KUA wilayah kota yang mendapat predikat Teladan di tahun 2013. Namun di wilahnya dini menjadi trend di kalayangan remaja. Rumusan masalah yang diangkat, pertama, upaya apa saja yang dilakukan KUA Kecamatan Gondomanan Yogyakarta dalam menanggulangi pernikahan dini pada Tahun 2014-2015. Kedua, Bagaimana efektivitas dari upaya yang dilakukan KUA Kecamatan Gondomanan Yogyakarta. Metode yang digunakan field research. Sifat penelitian yaitu deskriptif analitik serta pendekatan yang digunakan adalah pendekatan normatif dan yuridis. Alhasil KUA Gondomanan untuk terus melakukan upaya pencegahan pernikahan dini ini (KUA Gondomanan is an office which is located in the city that reached reward of Model in 2013, But in the beginning, the wages became a trend among teenagers. The current research arose from these two questions; first, what efforts were made by KUA of Gondomanan in tackling a child marriage in 2014-2015, and second, to what extent the effectiveness of the effort made by KUA of Gondomanan. This research was conducted by implementing field research through analytic descriptive research and normative and juridical approach. The data was obtained by conducting observation and interviews. KUA Gondomanan to continously make efforts to prevent the child marriage)
\end{abstract}

Kata Kunci:

Pernikahan Dini;KUA Gondomanan;Efektivitas

\section{Pendahuluan}

Available online at:

http://ejournal.iainmadura.ac.id/index.php/almanhaj/index

email koresproden: theadora42@gmail.com 
Pernikahan Usia Dini memiliki dua makna, yakni kata "pernikahan" dan kata "usia dini". Pengertian pernikahan menurut Kamus Besar Bahasa Indonesia memiliki arti hal (perbuatan) nikah; upacara nikah. Kata pernikahan sendiri berasal dari kata "nikah" yang memiliki arti perjanjian antara laki-laki dan perempuan untuk bersuami istri (dengan resmi). ${ }^{1}$

Pernikahan merupakan bentuk kata serapan dari "Perkawinan". Menurut bahasa Arab, perkawinan berasal dari kata النكاح yang berarti menghimpun dan mengumpulkan. Sedangkan kata "usia dini" memiliki arti umur yang masih muda, umur yang belum mencapai dewasa, umur yang masih belia. Jika kedua kalimat tersebut digabungkan akan memiliki arti bahwa pernikahan usia dini adalah suatu pernikahan yang salah satu pihak atau kedua pihak (calon istri dan calon suami) masih berusia di bawah umur yakni belum mencapai batas usia nikah, kisaran belasan tahun.

Allah telah berfirman dalam QS. An-Nisa (4): 6

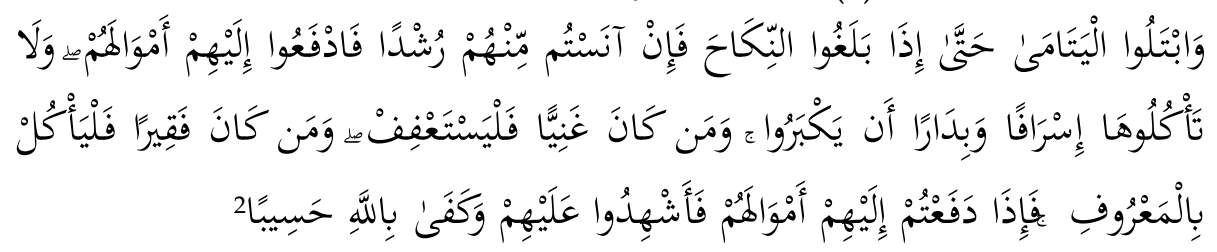

Dan ujilah anak yatim itu sampai mereka cukup umur untuk kawin. Kemudian jika menurut pendapatmu mereka telah cerdas (pandai memelihara harta), maka serahkanlah kepada mereka harta-hartanya. Dan janganlah kamu makan harta anak yatim lebih dari batas kepatutan dan (janganlah kamu) tergesa-gesa (membelanjakannya) sebelum mereka dewasa. Barang siapa (di antara pemelihara itu) mampu, maka hendaklah ia menahan diri (dari memakan harta anak yatim itu) dan barangsiapa yang miskin, maka bolehlah ia makan harta itu menurut yang patut. Kemudian apabila kamu menyerahkan harta kepada mereka, maka hendaklah kamu adakan saksi-saksi (tentang penyerahan itu) bagi mereka. Dan cukuplah Allah sebagai Pengawas (atas persaksian itu).

1 Tim Penyusun Kamus (Pusat Pembinaan dan Pengembangan Bahasa), Kamus Besar Bahasa Indonesia, cet. IV(Jakarta: Balai Pustaka, 1995), hlm. 689.

${ }^{2}$ QS. An-Nisa (4): 6 
Pernikahan dini adalah pernikahan yang dilangsungkan pada masa remaja. Menurut WHO (World Health Organization), batasan usia remaja adalah 12-24 tahun, sedangkan menurut Departemen Kesehatan rentang usianya antara 10-19 tahun dengan catatan "belum menikah", dan menurut Direktorat Remaja dan Perlindungan Hak Reproduksi BKKBN (BadanKoordinasi Keluarga Berencana Nasional) batasannya 10-21 tahun. ${ }^{3}$ Berdasarkan batasan umur yang ditetapkan oleh tiga lembaga di atas, maka dalam hal ini nikah dini bisa juga disebut dengan nikah muda atau nikah remaja.

Sebagaimana hadis Nabi Muhammad:

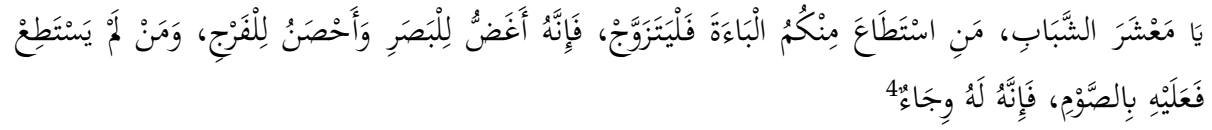

Wahai para pemuda barangsiapa di antara kamu sekalian mampu melakukan nikah maka hendaklah ia menikah. Maka sesungguhnya (dengan nikah bisa) lebih menundukkan terhadap pandangan dan menjaga kehormatan. Dan barang siapa tidak mampu (melakukan nikah) maka hendaklah ia berpuasa menjadi tameng baginya

Pernikahan dini adalah suatu akad yang terjadi antar insan lawan jenis yang pada dasarnya usia mereka bisa dikatakan masih muda. Tak sedikit orang yang beranggapan bahwa menikah di usia muda adalah suatu hal yang tabu, karena pandangan masyarakat yang cenderung negatif. Akan tetapi rata-rata mereka tidak bisa menunjukkan bukti bahwa masyarakat benar-benar memiliki penilaian negatif terhadap pernikahan dini. ${ }^{5}$

Pernikahan usia dini jelas bahwa ada unsur pelanggaran terhadap hak anak yang diatur pada undang-undang Perlindungan Anak. Hal pertama yang menjadi bahasan adalah tentang peran orang tua, bahwa kecenderungan yang terjadi dalam pernikahan dini adalah faktor ekonomi. Pernikahan dini yang terjadi selama ini terlihat bahwa pada umumnya adalah pengalihan tanggung jawab

3 Jazimah Al Muhyi, Jangan Sembarang Nikah Dini, cet. Ke-1 (Bandung: Lingkar Pena Kreativa), 2006, hlm. 12.

${ }^{4}$ Imam Muhammad bin Ismâ'îl al- Bukhârî, Sahîh al-Bukhârî , kitâban-nikâ ḥ, (Lebanon:Dar al-Kutub al-'Ilmiyah, 2010), hadits nomor.5066, hlm. 208.

5 Arif Yosodipuro, Saya Terima Nikahnya (Panduan Mempersiapkan dan Menjalani Pernikahan Islami), (Jakarta: Gramedia Pustaka Utama, 2010), hlm. 47. 
orang tua yang sebenarnya dalam Undang-undang ini seharusnya orang tua mencegah adanya pernikahan pada usia anak-anak yang tentunya hal tersebut bertujuan untuk menjaga hak-hak anak. Selain adanya peraturan tentang pencegahan pernikahan pada usia anakanak, juga sebenarnya ketika kita melihat batasan usia anak dalam Undang-undang Perlindungan anak adalah 18 tahun sehingga tentunya akan sangat bertentangan ketika ada praktek pernikahan di bawah batasan umur tersebut. ${ }^{6}$

Batas umur calon mempelai juga diatur di dalam Kompilasi Hukum Islam yakni pada pasal 15 yang berbunyi:

1. Untuk kemaslahatan keluarga dan rumah tangga perkawinan hanya boleh dilakukan calon mempelai yang telah mencapai umur yang ditetapkan dalam pasal 7 Undang-undang Perkawinan No. 1 Tahun 1974 yakni calon suami sekurangkurangnya berumur 19 tahun dan calon istri sekurangkurangnya 16 tahun.

2. Bagi calon mempelai yang belum mencapai umur 21 tahun harus mendapat izin sebagaimana yang diatur dalam pasal 6 ayat (2), (3), (4) dan (5) Undang-undang Perkawinan No. 1Tahun $1974 .^{7}$

Di Indonesia, dua kelompok organisasi yang sudah tidak asing ini yakni Muhammadiyah dan Nahdlatul 'Ulamā, memberikan persepsi yang berbeda terkait batasan usia nikah. Kelompok Muhammadiyah sepakat dengan aturan hukum positif di Indonesia yakni yang termuat dalam Undang-Undang Perkawinan No. 01 Tahun 1974 Bab II pasal 7 ayat 1 yang menyatakan bahwa "Perkawinan hanya dapat diijinkan jika pihak pria sudah mencapai usia 19 tahun dan pihak wanita sudah mencapai usia 16 tahun". Kelompok ini sepakat dengan aturan yang telah diberlakukan dengan alasan bahwa usia pernikahan perempuan 16 tahun dan laki-laki adalah 19 tahun adalah usia yang ideal untuk membentuk bahtera rumah tangga. Di

${ }^{6}$ DPR RI, Undang-undang Nomor 7 Tahun 1989 tentang Peradilan Anak, Varia Peradilan, Nomor 291 Tahun XXV Februari 2010, hlm. 35-44.

7 Undang-undang No. 1 Tahun 1974 tentang Perkawinan, Pasal 15, ayat (1) dan (2),. 
usia ini, kelompok Muhammadiyah menganggap bahwa usia di mana calon istri dan calon suami telah siap mental dan juga fisiknya. ${ }^{8}$

Berbeda dengan kelompok organisasi Nahdlatul 'Ulamâ yang menyatakan bahwa hakikatnya tidak ada aturan yang mengatur tentang batasan usia menikah, jadi tidak ada ketentuan minimal untuk boleh melakukan suatu akad pernikahan. Ini berarti sesorang dikatakan boleh melakukan pernikahan ketika si calon suami maupun calon istri telah akil baligh.

Sesuai dengan hukum sebab akibat, maka menikah pada usia muda sudah pasti ada poin minus dan plusnya. Keuntungan menikah di usia muda di antaranya adalah: mendapatkan pahala, membawa keberkahan, usia dalam masa produktif, mempunyai tempat berbagi, hati menjadi menjadi tentram dan penuh kasih sayang, sekaligus menjadikan pribadi lebih dewasa. Sedangkan kerugiannya adalah: tingkat ego yang masih tinggi, waktu untuk diri sendiri menjadi berkurang,cita-cita menjadi korban akibat menikah muda, prestasi belajar menurun, kerentanan terhadap masalah ${ }^{9}$

\section{Metodologi penelitian}

Jenis penelitian yang digunakan adalah penelitian lapangan (field research) dengan menggunakan observasi dan interview. Adapun penelitian lapangan digunakan untuk mencari data primer yang diperoleh secara langsung dari para pelaku pernikahan dini, tokoh masyarakat serta lembaga-lembaga yang terkait dalam bidang pernikahan dini khususnya oleh masyarakat Kecamatan Gondomanan Yogyakarta.

Penelitian ini bersifat deskriptif-analitik dengan tujuan menggambarkan secara sistematik, fakta dan karakteristik mengenai populasi atau bidang tertentu, yaitu dengan memaparkan gambaran

8http://indo.wsj.com/posts/2014/12/10/pro-kontra-batas-usiapernikahan/ diakses pada hari Sabtu, 21 Januari 2017. 18.13 WIB.

9 Arif Yosodipuro, Saya Terima Nikahnya (Panduan Mempersiapkan dan Menjalani Pernikahan Islami), (Jakarta: Gramedia Pustaka Utama, 2010), hlm. 4 lihat juga Erie Hariyanto, "BURGELIJK WETBOEK (Menelusuri Sejarah Hukum Pemberlakuannya Di Indonesia)," Al-Ihkam: Jurnal Hukum Dan Pranata Sosial 4, no. 1 (3 September 2013): 140-52. 
tentang Kantor Urusan Agama (KUA) Gondomanan sebagai wadah pencegahan pernikahan dini di Kecamatan Gondomanan Yogyakarta.

Bentuk penelitian adalah berupa evaluatif yaitu peneliti melakukan dengan cara pengumpulan data atau informasi terkait data pernikahan dini untuk selanjutnya dibandingkan dengan kriteria yang kemudian diambil kesimpulan. Penulis melakukan survey, observasi dan interview langsung di Kantor Urusan Agama (KUA) Gondomanan Yogyakarta untuk memperoleh gambaran bagaimana langkah upaya pencegahan pernikahan dini. Penulis melakukan interview atau wawancara terhadap empat orang dari instansi terkait dalam pernikahan dini yaitu kepala KUA, Kepala BP4, staff PUSKESMAS dan Kepala PLKB (Petugas Lapangan Keluarga Berencana) Kecamatan Gondomanan Yogyakarta. Mengumpulkan dokumen seperti data-data, artikel, buku-buku ataupun segala bentuk dokumentasi yang terkait sebagai bahan penguat dalam penelitian ini.

Metode pendekatan normatif, yaitu pendekatan terhadap pokok masalah yang diteliti terkait efektifitas pencegahan pernikahan dini di KUA Kecamatan Gondomanan Yogyakarta tahun 2014-2015 dan pendekatan yuridis, yakni disesuaikan dengan perundangundangan yang berlaku di Indonesia (hukum positif).

Analisis data merupakan suatu cara yang digunakan untuk menganalisis, mempelajari serta mengolah data tertentu, sehingga dapat diambil kesimpulan yang konkret tentang persoalan yang diteliti. ${ }^{10}$ Sesuai dengan penulisan ini maka dalam menganalisis data yang diperoleh menggunakan teknik deskriptif kualitatif, yakni menggambarkan data-data yang diperoleh dengan dipisah-pisah menurut kategori untuk memperoleh kesimpulan. Adapun penalaran yang akan digunakan yaitu metode deduktif, dengan menggunakan pola penerapan penalaran dengan mengaplikasikan atau menghubungkan hukum dan teori yang ada dengan fenomena yang terjadi.

\section{Analisis Teori}

10 Suharsimi Arikunto, Prosedur Penulisan: Suatu Pendekatan Praktik, (Jakarta: Bumi Aksara, 1995), hlm. 202. 


\section{A. Faktor-faktor pernikahan dini}

Di Indonesia, pernikahan dini masih sering terjadi yakni pada usia di bawah 15 tahun. Hal ini disebabkan salah satunya adalah faktor ekonomi. Tingkat ekonomi yang rendah seringkali dialami oleh kaum bawahan (keluarga miskin) dengan alasan dapat mengurangi beban tanggungan dari orang tua. Sehingga ketika anak dinikahkan lebih muda ada harapan supaya anak mendapatkan kehidupan yang lebih baik dan sejahtera. Selain dari yang disebut di atas, faktor penyebab anak menikah di usia dini adalah karena adanya unsur keterpaksaan dari pihak orang tua untuk melakukan pernikahan dini. ${ }^{12}$

Berikut beberapa yang menjadi penyebab adanya pernikahan dini, di antaranya:

a. Faktor Budaya

Budaya adalah sesuatu yang sudah menjadi kebiasaan yang sulit untuk dirubah. ${ }^{13}$ Budaya atau kebiasaan menjodohkan anak ketika masih kecil menjadi salah satu penyebab adanya pernikahan dini. Di beberapa tempat seperti contohnya di daerah Bangkalan dan Madura sampai saat ini, meski tinggal sedikit masih berlaku menjodohkan anak-anaknya sejak kecil. Sehingga apabila sudah berlaku yang namanya budaya yang melekat sebagai anak hanya bisa mengikuti apa kata orang tua yan telah menjodohkannya sejak kecil.

b. Faktor Pendidikan

Rendahnya tingkat pendidikan yang dimiliki orang tua akan memberikan pengaruh terhadap perilakunya. Orang tua yang memiliki pendidikan minim akan beranggapan bahwa menjadi anak perempuan tidak perlu sekolah tinggi-tinggi karena ujungnya hanya sebagai ibu rumah tangga. Selain itu, pendidikan anak yang terputus menjadi alasan orang tuanya untuk segera menikahkannya.

c. Faktor Ekonomi

Faktor ekonomi merupakan faktor yang kebanyakan menjadikan alasan ketika orang tua menikahkan anaknya di usia yang masih muda, hal ini dimaksudkan supaya anak bisa hidup lebih baik dengan calon pasangannya sehingga meringankan beban orang tuanya.

d. Faktor Jauh dari Orang Tua 
Tak sedikit anak-anak yang dirawat dan diasuh oleh kakekneneknya, sementara orang tua bekerja dan merantau di luar pulau, sehingga terkadang perlakuan kakek-nenek yang terlalu memanjakan cucunya memberikan kebebasan terhadap pergaulan cucunya dengan lawan jenis. Maka seringkali, ketika kakekneneknya timbul kekhawatiran akan perzinaan sehingga mengusulkan untuk menyegerakan pernikahan. ${ }^{11}$

Upaya pencegahan pernikahan dini di Kantor Urusan Agama Gondomanan Yogyakarta tahun 2014-2015.

KUA Gondomanan juga mempunyai peran yang salah satunya dalam rangka mengurangi angka pernikahan dini. Mengapa pernikahan dini mendapat perhatian khusus di KUA Gondomanan? Karena jumlah pernikahan dini di tahun 2013 adalah yang memprihatinkan, di mana banyak remaja yang usianya masih muda telah melakukan pernikahan, sehingga di tahun 2014-2015 KUA Gondomanan dengan khusus memperhatikan dan melakukan tindakan supaya praktik pernikahan dini di tahun tersebut bisa diminimalisir yakni dengan adanya upaya pencegahan pernikahan dini dengan menekan pernikahan yang di bawah umur. Ini artinya, pihak KUA berhak menolak calon pengantin yang mendaftar di KUA ketika usia mereka belum mencapai umur. Berikut data pernikahan rujuk, talak dan cerai (menurut umur) di KUA Gondomanan pada tahun 2014-2015.

Tabel: 1

DATA PERNIKAHAN RUJUK, TALAK DAN CERAI (MENURUT UMUR) BULAN JANUARI S/D DESEMBER 2015

\begin{tabular}{|l|l|l|l|l|}
\hline & $\begin{array}{l}\text { Kelu- } \\
\text { rahan }\end{array}$ & $\begin{array}{c}\text { Ngupa- } \\
\text { san }\end{array}$ & $\begin{array}{c}\text { Prawiro- } \\
\text { dirjan }\end{array}$ & Jumlah \\
\cline { 2 - 5 } & $\mathrm{P} / \mathrm{L}$ & & & \\
\hline
\end{tabular}

11 Tim Penyusun Kamus (Pusat Pembinaan dan Pengembangan Bahasa), Kamus Besar Bahasa Indonesia, cet. IV (Jakarta: Ed. II, Balai Pustaka, 1995), hlm. 689 


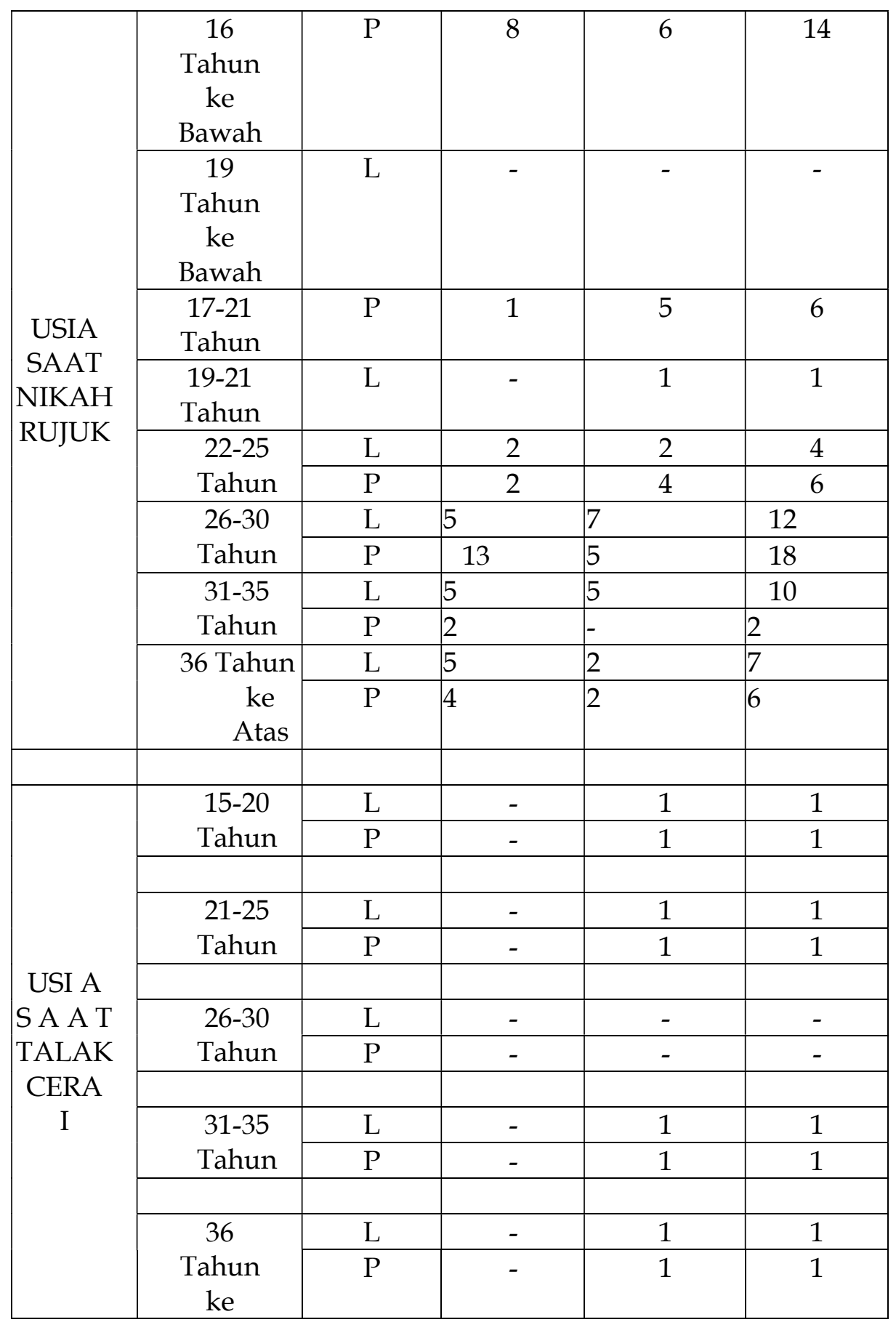




\begin{tabular}{|l|l|l|l|l|l|}
\hline & Atas & & & & \\
\cline { 2 - 6 } & & & & & \\
\hline
\end{tabular}

Sumber : Data KUA (Kantor Urusan Agama) Kecamatan Gondomanan Yogyakarta Tahun 2014-2015

Adapun upaya-upaya yang dilakukan Kantor Urusan Agama (KUA) Gondomanan dalam melakukan pencegahan pernikahan dini di antaranya:

1. Penyuluhan atau Sosialisasi

Berdasarkan data yang diperoleh penulis, tercatat bahwa di tahun ini angka pernikahan dini adalah sebanyak delapan orang, empat orang dari pihak laki-laki dan empat orang dari pihak perempuan dari 164 orang pasangan yang menikah di KUA Kecamatan Gondomanan dalam hitungan satu tahun yakni tahun 2014. Hal ini masih dikatakan dalam batas normal, namun tetap menjadi catatan sendiri bagi KUA Gondomanan, supaya di tahun berikutnya bisa berkurang lagi sehingga praktik pernikahan dini tidak terjadi lagi masyarakat; pemasyarakatan. ${ }^{1}$

Kegiatan berupa penyuluhan atau sosialisasi merupakan langkah pertama yang dilakukan KUA. Kegiatan ini lebih banyak dilakukan dengan metode ceramah dan tanya jawab terhadap remaja langsung. Ini dilakukan dengan cara pihak KUA dan lembaga lintas sektoral melakukan kunjungan melalui sekolah-sekolah. Hal ini dimaksudkan supaya materi dan juga teori perihal pernikahan bisa tersampaikan dengan baik ke remaja.

\section{Penyiapan Kehidupan Berkeluarga bagi Remaja}

Remaja dibekali berbagai ilmu pengetahuan, mulai dari ilmu kesehatan, ekonomi, psikologi, pendidikan, sosial dan ilmu agama yang kuat. Hal ini menjadi tanggung jawab sekaligus peran dari orang tua remaja, lingkungan sekolah, lingkungan masyarakat sekitar, lingkungan media, sekaligus pola pergaulan yang sesuai dan mendukung.

Secara sederhana, penyiapan kehidupan berkeluarga bagi remaja adalah upaya untuk menumbuhkembangkan kehidupan remaja yang tegar dalam rangka memasuki kehidupan berkeluarga melalui penyiapan remaja tentang konsep dan contoh kehidupan berkeluarga yang ideal. Di mana tujuan dari penyiapan kehidupan 
bagi remaja adalah untuk memperkaya dan meningkatkan kualitas kehidupan individu dan keluarga.

3. Pendewasaan Usia Perkawinan dan Perencanaan Keluarga

Pendewasaan usia perkawinan adalah upaya untuk meningkatkan usia pada perkawinan pertama, sehingga pada saat perkawinan mencapai usia minimal 20 tahun bagi perempuan dan 25 tahun bagi laki-laki. Batasan usia ini dianggap sudah siap baik dilihat dari sisi kesehatan maupun perkembangan emosional untuk menghadapi kehidupan berkeluarga. PUP dalam hal ini bukan sekedar menunda perkawinan sampai usia tertentu saja, namun juga mengusahakan agar kehamilan pertama terjadi pada usia yang cukup dewasa.

PUP merupakan bagian dari program Keluarga Berencana Nasional yang dalam hal ini sekaligus diterapkan oleh instansi lintas sektoral PLKB (Petugas Penyuluh Keluarga Berencana) atau PIKR (Pusat Informasi Komunikasi Remaja).

Upaya-upaya yang telah dilakukan KUA Gondomanan merupakan langkah untuk menerapkan Undang-undang Nomor 1 Tahun 1974 pasal 7 ayat 1 mengenai batas minimal usia menikah, yang berbunyi: "Perkawinan hanya diizinkan bila pihak pria mencapai umur 19 (Sembilan belas) tahun dan pihak wanita sudah mencapai usia 16 (enam belas) tahun." 2

Meskipun undang-undang menentukan batas minimal usia pernikahan yakni 16 dan 19 tahun, tetapi dianjurkan bagi mereka untuk menunda proses kehamilan sampai si istri berusia 20 tahun. Hal ini dilakukan adalah untuk menghindari resiko yang tidak diinginkan oleh kedua pasangan tersebut.

Berdasarkan hasil wawancara dengan salah satu pihak PLKB (Penyuluh Lapangan Keluarga Berencana), yakni dengan Ibu Sudaryati bahwa beliau menyebutkan seseorang dikatakan telah siap menjalani suatu perkawinan adalah ketika calon pasangan suami istri, keduanya telah mampu dalam hal ekonomi, fisik dan juga mental, calon pasangan suami istri harus saling memahami dan mengerti satu sama lain, dapat mengontrol emosi masing-masing, sehingga ketika masalah datang menghampiri bisa diselesaikan oleh kedua belah pihak dengan kepala dingin. 
kesadaran yang kurang baik dari masyarakatnya maupun remajanya Pada dasarnya perkawinan mempunyai hubungan yang erat dengan masalah kependudukan, sehingga adanya pernikahan dini yang jika dibiarkan semakin bertambah angkanya maka secara tidak langsung akan mengakibatkan laju kelahiran bayi yang lebih tinggi, hal ini yang dikhawatirkan akan berpengaruh terhadap kualitas anak yang dihasilkan dari pernikahan dini.

KUA (Kantor Urusan Agma) sebagai lembaga yang menangani khusus di bidang perkawinan sudah semestinya untuk melakukan tindakan preventif atau upaya pencegahan, hal ini dikarenakan menikah dini memiliki resiko yang tinggi terutama bagi si calon ibu dalam mengandung bayinya. Upaya ini sesuai dengan kaidah ushul Fiqih yang berbunyi:

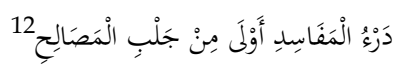

Kaidah tersebut memberikan keterangan bahwa menolak kerusakan (mafsadat) lebih didahulukan daripada mencari kebaikan (kemaslahatan). Apabila seseorang menimbulkan bahaya yang nyata pada hak orang lain sedangkan bahaya tersebut dapat dikendalikan dengan melakukan pencegahan maka, orang tersebut dapat dipaksa untuk mengambil langkah- langkah pencegahan untuk mencegah tersebut.

Berkaitan dengan hal ini, sejauh pengamatan yang dilakukan peneliti segala bentuk upaya yang diprogramkan oleh pihak KUA Gondomanan beserta lintas sektoralnya dalam rangka pencegahan pernikahan dini adalah efektif namun belum bisa dikatakan maksimal karena dari beberapa program yang dijalankan KUA Gondomanan belum sepenuhnya bisa diterapkan oleh masyarakatnya, seperti adanya sosialisasi pencegahan pernikahan dini atau penyuluhan tentang kesehatan remaja dan sebagainya, masih ada keengganan dan. Ini artinya, tingkat kepedulian masyarakat terlebih remajanya yang harus lebih diperhatikan. Namun demikian berbagai upaya yang diprogramkan KUA Gondomanan beserta lintas sektoralnya sudah baik, tinggal proses penerapannya.

12 Nashr Farid Muhammad Washil dan Abdul Aziz Muhammad Azzam, alih bahasa. Ed.Qawa'id Fiqhiyyah, (Jakarta: Amzah, 2013), hlm. 21. 


\section{Efektivitas Pencegahan Pernikahan Dini Kantor Urusan Agama Godomanan Tahun 2015}

Adapun upaya-upaya yang dilakukan Kantor Urusan Agama (KUA) Gondomanan dalam melakukan pencegahan pernikahan dini di antaranya:

a. Pembinaan

Kegiatan pembinaan adalah langkah dalam upaya pencegahan pernikahan dini. Kegiatan pembinaan dilakukan oleh pihak-pihak atau staf bidang dari Kantor Urusan Agama (KUA) Gondomanan. Kegiatan Pembinaan dalam hal ini dibagi menjadi 3 tipe:

i. Pembinaan terhadap Remaja

ii. Pembinaan terhadap Orang Tua Remaja

iii. Pembinaan Pasca Nikah

Pembinaan pertama adalah dengan sasaran para remaja seperti karang taruna, remaja masjid, anak-anak sekolah tingkat SMP-SMA/ SMK sederajad. Hal ini dimaksudkan adalah tidak lain supaya kegiatan pembinaan mengenai pendidikan tentang seks, pendidikan tentang seluk- beluk pernikahan bisa langsung diterima oleh para remaja sehingga tidak menimbulkan pemahaman yang keliru ketika dihadapkan oleh para pakar mengenai hal tersebut. Kegiatan pembinaan ini diselenggarakan oleh KUA Gondomanan yang rutin diadakan dalam setahun empat kali. Selama empat kali ini kegiatan bisa bertempat di ruang aula KUA Gondomanan bisa juga dengan mengunjungi langsung ke sekolahan-sekolahan dengan jadwal yang sudah disepakati sebelumnya.

Adanya kegiatan pembinaan seperti ini banyak dari mereka, para remaja yang antusias karena pendidikan dan juga pemahaman tentang pernikahan sangat dibutuhkan bagi mereka sejak awal terlebih bagi mereka yang mulai mengenal lawan jenisnya.

Tipe pembinaan kedua adalah dengan sasaran orang tua remaja, hal ini perlu dilakukan karena orang tua dalam hal ini sangat berpengaruh terhadap perkembangan anak remajanya. Orang tua dalam hal ini diberikan pemahaman mengenai pola 
pergaulan anak remaja era kini, sehingga diharapkan nantinya selain anak mendapatan ilmu dan pengetahuan di sekolahan, orang tua juga selalu memberikan pendidikan moral dan juga pengetahuan tentang agama supaya anak remajanya tidak sampai salah arah maupun kelewat batas. Ini juga dimaksudkan supaya orang tua melakukan pengawasan yang lebih terhadap anak remajanya supaya sebagai anak juga bisa membentengi diri terhadap pola pergaulannya. Adanya pembinaan yang diberikan pihak KUA Gondomanan oleh orang tua remaja diharapkan orang tua ikut serta dalam upaya mencegah pernikahan dini dengan memberikan wejangan-wejangan maupun nasehat kepada anak remajanya.

Tipe pembinaan yang ketiga adalah diberikan kepada pasangan pasca menikah, ini artinya pembinaan diberikan bagi mereka yang telah melakukan pernikahan baik itu menikah diusia ideal maupun menikah diusia dini. Pembinaan ini diselenggarakan bagi pasangan yang telah menjalani usia pernikahan 1-5 tahun. Jadi pembinaan ini tidak berlaku bagi mereka yang usia pernikahannya melebihi 5 tahun ke atas. Hal ini dimaksudkan karena usia pernikahan 1-5 tahun adalah usia yang rentan timbul konflik.

b. Kerja sama dengan instansi terkait

Bentuk upaya pencegahan pernikahan dini yang dilakukan KUA Gondomanan yang kedua ini adalah berupa menjalin kerja sama dengan instansi atau lembaga yang lain, yakni dengan lembaga yang mempunyai kewenangan yang sama untuk mengurangi angka atau jumlah pelaku yang menikah di usia muda. Lembaga atau instansi yang bekerja sama dengan KUA Gondomanan adalah antara lain: BP4 (Badan Penasehatan Pembinaan dan Pelestarian Perkawinan), Puskesmas (Pusat Kesehatan Masyarakat), dan PLKB (Penyuluhan Lapangan Keluarga Berencana) atau PIKR (Pusat Informasi Komunikasi Remaja). Berikut penjelasan mengenai upaya yang dilakukan dalam mengurangi jumlah pernikahan dini di Gondomanan:

i. Upaya Pencegahan Pernikahan Dini oleh BP4 Gondomanan

BP4 Kecamatan sifatnya memberikan penasehatan sebelum menikah terhadap calon pengantin. Upaya pencegahan yang dilakukan BP4 berupa: pembinaan 
wilayah RW, masing-masing RW dimintai 2 orang untuk perwakilan, bekerja sama dengan remaja masjid, sudah pasti remaja muslim yang bergerak dalam hal ini yang memiliki kegiatan aktif di masjid, berbeda dengan kerja sama dengan wilayah RW ada perbedaan di mana remaja ada yang muslim ada yang bukan muslim, kerja sama dengan PIK R, kerja sama dengan PKK, pembinaan terhadap orang tua remaja. Dalam penyampaiannya ketika proses wawancara bersama Ibu Wiji Lestari, beliau menyampaikan: "UU Nomor 1 Tahun 1974 sudah kuno, sudah seharusnya dilakukan perubahan pasalnya kurang ngetop jika batas usia menikah untuk perempuan 16 tahun, 19 tahun untuk laki-laki, karena kesiapan fisik dan juga mental hal ini juga harus diperhatikan".

Beliau menambahkan bahwa rahim perempuan untuk melahirkan belum kuat atau belum siap. Usia matang paling tidak 20 tahun untuk perempuan dan 25 tahun untuk laki-laki sehingga kesiapan fisik dan juga mental setidaknya sudah matang dan dewasa, artinya telah siap jika nanti langsung mendapati proses kehamilan. Beliau juga menyampaikan beberapa kasus yang sering ditemui ketika berhadapan dengan masyarakat ketika melakukan proses penasehatan, seperti kasus kecelakaan, artinya telah hamil di luar ikatan yang sah. Peran BP4 sendiri dalam upaya pencegahan pernikahan dini antara maksimal dan tidak maksimal, pengadaan kegiatan harus dengan proposal. Karena keterbatasan dana.

ii. Upaya Pencegahan Pernikahan Dini oleh PUSKESMAS Gondomanan:

a. Fase Menunda Kehamilan pada usia dini atau usia rentan (kurang dari 20 tahun)

b. Fase Menjarangkan Kehamilan

iii. Upaya Pencegahan Pernikahan Dini oleh PLKB Gondomanan:

a. PIK R (Pusat Informasi dan Komunikasi Remaja)

b. BKR (Bina Keluarga Berencana), orang tua dilibatkan

c. PUP (Pendewasaan Usia Perkawinan)

d. KESPRO (Kesehatan Reproduksi) 
Pada dasarnya, jika dilihat dari segi normatif (hukum positif) dan juga hukum Islam, tidak ada aturan yang menjelaskan tentang pencegahan pernikahan dini, ini dikarenakan tidak ada buku atau kitab khusus yang menjelaskan mengenai pencegahan pernikahan dini. Segala sesuatu yang menimbulkan madlarat dan mafsadat memang harus dihindarkan karena takut akan dampak yang timbul nantinya. Pernikahan dini sudah semestinya dihindarkan di era millennium ini, karena jika dilakukan akan berdampak pada pasangan yang menikah dini terutama pihak istri yang karena belum siap fisiknya jika terjadi kehamilan, akan rentan timbul penyakit dan bahaya bagi rahimnya. Di dalam aturan Undang-Undang No. 1 Tahun 1974 hanya terdapat mengenai aturan Pencegahan Perkawinan, aturan ini berlaku bagi orang yang tidak memenuhi syarat-syarat untuk melangsungkan perkawinan. Berikut bunyi pasal 13 mengenai pencegahan perkawinan: "Perkawinan dapat dicegah apabila ada orang yang tidak memenuhi syarat-syarat untuk melangsungkan perkawinan". Aturan ini diperkuat lagi dengan bunyi pasal 14 bahwa: "Yang dapat mencegah perkawinan adalah para keluarga dalam garis keturunan lurus ke atas dank e bawah, saudara, wali nikah, wali pengampu dari salah seorang calon mempelai dan pihak-pihak yang berkepentingan" "mereka yang tersebut dalam ayat (1) pasal ini berhak juga mencegah berlangsungnya perkawinan apabila slaah seorang dari calon mempelai berada di bawah pengampuan, sehingga dengan perkawinan tersebut nyata-nyata mengakibatkan kesengsaraan bagi calon mempelai yang lain yang mempunyai hubungan dengan orang-orang seperti yang tersebut dalam ayat (1) pasal ini."

Pada dasarnya upaya pencegahan pernikahan dini yang dilakukan KUA kecamatan Gondomanan Yogyakarta beserta lintas sektoralnya baik antara tahun 2014 maupun 2015 upaya yang dilakukan adalah sama, namun dalam hal ini upaya dalam menanggulangi pernikahan dini di tahun 2014 lebih banyak dilakukan dengan kegiatan sosialisasi atau penyuluhan terhadap remajanya secara langsung, baru di tahun 2015 kegiatan dalam rangka menanggulangi pernikahan 
dini berupa pembinaan-pembinaan dengan mengadakan berbagai pelatihan-pelatihan khusus baik terhadap remaja, orang tua maupun pelaku nikah dini, di tahun ini juga lembaga lintas sektoral ikut serta dalam rangka upaya meminimalisir angka pernikahan dini.

Peran Kantor Urusan Agama (KUA) Gondomanan dalam upaya mencegah ataupun mengurangi angka pernikahan dini terutama di tahun 2014-2015 sudah berjalan baik. Ini terbukti dengan menurunnya jumlah pernikahan dini di Gondomanan namun ada beberapa yang menjadi hambatan atau kendala dalam melakukan upaya tersebut. Di antara kendala yang dialami KUA Gondomanan dalam upaya pencegahan pernikahan dini adalah tingkat kesadaran masyarakat yang rendah baik itu oleh remajanya sendiri, orang tua remaja dan juga lembaga lintas sektoralnya. Pemahaman tentang agama yang sedikit, pola pergaulan remaja yang bebas yang tidak sebanding dengan didikan orang sekitar, dan juga keterbatasan relawan dalam melakukan tindakan-tindakan preventif dari adanya pernikahan dini.

Beberapa problematika dan kendala yang dihadapi KUA Gondomanan dalam melakukan upaya pencegahan pernikahan dini adalah sebagai berikut:

a. Dana Operasional, adanya kegiatan pembinaan yang selama ini dilakukan satu tahun hanya empat kali, ini karena terbatasnya dana yang ada. Padahal semestinya kegiatan diadakan satu tahun setidaknya 12 kali pertemuan. Jadi satu bulan setidaknya ada kegiatan sekali untuk pembinaan, supaya bisa optimal.

b. Peserta, partisipasi peserta dalam kegiatan minim. Seperti yang disampaikan oleh Ibu Sudaryati selku Ketua dari PLKB:

"Ya kalau maksimal belum, karena gini, mengumpulkan remaja susah, kita saja yang punya program PIK R (Pusat Informasi dan Komunikasi Remaja) baik dari RW 11 maupun RW 12 Prawirodirjan masih sulit untuk mengumpulkan semua remaja karena masih belum lama berjalan selain itu kendala waktu menjadi alasan seperti 
misalnya remaja yang belum menikah namun sudah bekerja untuk mengikuti kegiatan perkumpulan bisanya jam malam, remaja yang masih sekolah juga karena pagi disibukkan dengan belajar di sekolah bisanya jam malam. Sehingga kegitan perkumpulan untuk RW 11 hanya dilaksanakan di malam minggu, sedangkan untuk di RW 12 malah jangan dilakukan di malam minggu, nah jadi penetuan waktunya yang susah untuk bisa "meet" atau bertemu dengan anggota remaja keseluruhan" ${ }^{13}$

c. Untuk PLKB (Petugas Lapangan Keluarga Berencana) yang memiliki program BKR (Bina Keluarga Remaja), dalam kegiatan ini belum semua RW mempunyai kelompok BKR, hanya ada empat RW yang sudah memiliki kader yakni RW 08, 11, 12, dan 15 padahal ada 18 RW. Ini yang menjadi kendala, kembali ke masyarakatnya sedikit banyak dari mereka yang masih beranggapan "tidak penting", "belum merasa butuh". Ketika petugas melakukan upaya sosialisasi melalui kader-kadernya yakni dengan melakukan tindakan "door to door", sering dipandang remeh dan terburu untuk melakukan penolakan. Mindset orang untuk merubah susah, untuk datang susah.

Minimnya jumlah tenaga, dibutuhkan sumber daya manusia yang handal sekaligus kredibel. Satu Kecamatan hanya dipasrahkan ke satu orang, kemampuan orang yang minim dengan program kerja yang tidak sedikit sehingga petugas kewalahan dalam memberikan pelayanan terhadap masyarakat yang membutuhkan.

Berdasarkan keterangan di atas maka secara umum problematika dan kendala yang dialami KUA Gondomanan dalam upaya pencegahan pernikahan dini adalah: Pertama, dana operasional yang kecil. Kedua, tingkat antusias sekaligus partisipasi peserta yang rendah. Ketiga, untuk lembaga PLKB (Petugas Lapangan Keluarga Berencana) belum semua RW mempunyai kelompok BKR (Bina

13 Wawancara dengan Ibu Sudaryati, beliau adalah Ketua PLKB (Penyuluh Lapangan Keluarga Berencana) Gondomanan Yogyakarta, pada Hari Senin, tanggal 20 Maret 2017, Pukul 09. 20 WIB. 
Keluarga Remaja). Keempat, terbatasnya sumber daya manusia atau minimnya jumlah tenaga.

Pada tahun 2015, bahwa upaya yang dijalankan KUA Gondomanan beserta lintas sektoralnya sudah semakin baik dan efektif, ini terbukti dengan adanya upaya pencegahan pernikahan dini tidak hanya melalui sosialisasi atau penyuluhan melainkan dengan adanya kegiatan- kegiatan positif terhadap remaja melalui pembinaan-pembinaan mengenai kesehatan remaja, pelatihanpelatihan khusus sehingga remaja dituntut untuk menghasilkan sekaligus menciptakan suatu karya yang bernilai guna juga positif. Keefektifan upaya KUA Gondomanan dan lintas sektoralnya ini juga dibuktikan dengan berkurangnya angka pernikahan dini di tahun ini (2015), tercatat bahwa di tahun 2014 berjumlah 8 orang pelaku nikah dini, dan di tahun 2015 hampir tidak ada yang melakukan pernikahan dini, hanya satu-dua orang yang melakukannya.

\section{Hasil penelitian}

Hasil penelitian menunjukkan bahwa praktik pernikahan dini masih terjadi di wilayah KUA Gondomanan Yogyakarta. Meskipun angka pernikahan dini tahun 2014-2015 tidak sebanyak tahun sebelumnya, namun dalam hal ini tetap menjadi catatan tersendiri KUA Gondomanan untuk terus melakukan upaya pencegahan pernikahan dini ini. Hal ini dimaksudkan supaya tahun-tahun berikutnya tidak ada lagi praktik pernikahan dini. Upaya yang dilakukan oleh KUA sebagai lembaga yang berwenang dalam meminimalisir angka pernikahan dini sebagai tindakan yang preventif di antaranya adalah 1) Mengadakan sosialisasi atau penyuluhan-penyuluhan dengan konsentrasi terhadap remaja. 2) Melakukan pembinaan-pembinaan baik terhadap remaja maupun orang tua. 3) Kerja sama dengan instansi terkait seperti BP4, PUSKESMAS maupun PLKB. Adapun kendala yang dihadapi KUA Gondomanan dalam upaya pencegahan pernikahan dini adalah 1) Rendahnya tingkat kesadaran masyarakat 2) Ketersediaan waktu yang terbatas 3) Kurangnya relawan atau kader yang mampu diajak kerjasama dalam upaya pencegahan pernikahan dini.

\section{Daftar Pustaka}

Tim Penyusun Kamus (Pusat Pembinaan dan Pengembangan Bahasa), Kamus Besar Bahasa Indonesia, cet. IV, Jakarta: Balai Pustaka, 1995. 
Jazimah Al Muhyi, Jangan Sembarang Nikah Dini, cet. Ke-1 Bandung: Lingkar Pena Kreativa, 2006

Hariyanto, Erie. "BURGELIJK WETBOEK (Menelusuri Sejarah Hukum Pemberlakuannya Di Indonesia)." Al-Ihkam: Jurnal Hukum dan Pranata Sosial 4, no. 1 (3 September 2013): 140-52.

Imam Muhammad bin Ismâ'îl al- Bukhârî, ßahîh al-Bukhârî , kitâbannikâ ḥ, Lebanon:Dar al-Kutub al-'Ilmiyah, 2010, hadits nomor.5066.

Arif Yosodipuro, Saya Terima Nikahnya (Panduan Mempersiapkan dan Menjalani Pernikahan Islami), Jakarta: Gramedia Pustaka Utama, 2010.

DPR RI, Undang-undang Nomor 7 Tahun 1989 tentang Peradilan Anak, Varia Peradilan, Nomor 291 Tahun XXV Februari 2010.

Undang-undang No. 1 Tahun 1974 tentang Perkawinan, Pasal 15, ayat (1) dan (2).

http://indo.wsj.com/posts/2014/12/10/pro-kontra-batas-usiapernikahan/ diakses pada hari Sabtu, 21 Januari 2017. 18.13 WIB.

Suharsimi Arikunto, Prosedur Penulisan: Suatu Pendekatan Praktik, Jakarta: Bumi Aksara, 1995.

Supraptiningsih, Umi;Ferdiant, Ahmad Ghufran;, Erie; Hariyanto, Eka; Susylawati, and Arif Wahyudi. "Empowering Pamekasan to Become a Child-Friendly Regency through Interpersonal Communication." Atlantis Press, 2018. https://doi.org/10.2991/iccsr-18.2018.36.

Nashr Farid Muhammad Washil dan Abdul Aziz Muhammad Azzam, alih bahasa. Ed.Qawa'id Fiqhiyyah, Jakarta: Amzah, 2013.

Wawancara dengan Ibu Sudaryati, beliau adalah Ketua PLKB (Penyuluh Lapangan Keluarga Berencana) Gondomanan Yogyakarta, pada Hari Senin, tanggal 20 Maret 2017, Pukul 09. 20 WIB. 